\title{
VEGETATION AND LANDSCAPE ON CRYSTALLINE LIMESTONE BEDROCK IN THE VICINITY OF LÁNOV (GIANT MOUNTAINS, CZECH REPUBLIC)
}

\author{
JITKA MÁLKOVÁ ${ }^{1}$ and KAREL MATĚJKA ${ }^{2, *}$ \\ ${ }^{1}$ Faculty of Sciences, University of Hradec Králové, Rokitanského 62, 50003 Hradec Králové, Czech Republic \\ ${ }^{2}$ IDS, Na Komořsku 2175/2a, 14300 Praha 4, Czech Republic \\ * Corresponding author: matejka@infodatasys.cz
}

\begin{abstract}
This paper evaluates the structure of the landscape and vegetation in an area of 106.4 ha near the quarry by the village Horní Lánov ( $4 \mathrm{~km}$ east of Vrchlabí) situated in a low part of the Giant Mountains. The bedrock (crystalline limestone), rugged terrain, soil moisture and management affect the biodiversity at this locality. It is botanically well known and a very valuable region because of the high number of nature conservation-important species and habitats that occur there. A total 517 species of vascular plants were recorded there between 2002 and 2010. The whole area was divided into 36 segments each with a relatively homogeneous vegetation cover consisting of particular species of plants. Classification of the segments was done using a numerical classification (Sörensen's similarity index) and Ellenberg's indicator values were used to describe the basic environmental features of the individual segments. The species presence/ absence data together with indicator values (light conditions, temperature, water availability, soil reaction and nitrogen activity) were evaluated. The PCA ordination of this data set distinguished three basic types of vegetation cover ("forest", "dry" and "wet") and that the species composition of the vegetation in the area is mostly determined by land-use (deforestation, limestone mining, pasturing and management of forests) and soil moisture.
\end{abstract}

Keywords: bioindication, classification, landscape structure, ordination, species richness

\section{Introduction}

The structure of landscape can be analysed at different scales - large regions displayed at a small scale that covers the whole area of a country or a larger area, or at a medium scale, in which the centre of attention is e.g. a mountain range or medium sized river-basin, or at a large scale of parts of a landscape consisting of a few tens of hectares (Farina 2006). The variability in landscape in the Giant Mountains depends on altitude. The landscape transects (Matějka 2010) can be assigned to a medium scale. This study operates in a large display scale. Results of investigations at a medium scale are suitable for classifying landscape segments based on levels of management in large protected areas (e.g. national parks and protected landscape areas; for example see Matějka 2010; Křenová and Hruška 2012). Analyses carried out at a large scale are not usually published because they rarely produce results suitable for publication in scientific journals.

This paper presents the results of a large scale landscape analysis. The area studied is in the foothills of the Krkonoše Mts. (Giant Mountains, Czech Republic) at the border of the Krkonoše National Park (NP). The landscape is determined by the local geology. Acid, nutrient-poor rocks predominate in the Giant Mountains and the basic rocks that rarely occur there (Faltysová et al. 2002) consist of spatially limited inserts of crystalline limestone. These localities are very important in terms of increasing the biodiversity in the area. Not only do different species of plants (often especially protected or endangered) occur at these localities but even specific phytocenoses and many species of other organisms that do not occur in the surroundings areas, or only rarely. Since limestone is an important building material it is often quarried at these localities, which often results in the devastation of a substantial part of these localities. One such locality is near Horní Lánov where there is a small quarry that was abandoned a long time ago and an operational quarry that is likely to continue working well into the future. Because in the area to be quarried there are lots of protected species (Corallorhiza trifida, Epipactis purpurata, Platanthera bifolia, Cephalanthera damasonium) that are abundant and occur there in representative biotopes (e.g. herbaceous plant rich and calcicolous beech forests, ash-alder alluvial woods), it is important to save these areas for posterity. That is why workers of the Administration of the Krkonoše NP ordered a detailed study of the area near the operational quarry and in the wider surroundings of both quarries. This resulted in unpublished manuscripts by Dřevíkovský (2000) and Málková (2005). The extraordinary scientific value of this area is well established based on historical floristic data (Málková et al. 2004, 2006; Málková 2007).

If the floristic data for only a few segments of landscape are processed it is difficult to evaluate the similarity of such segments only on the basis of species similarity (e.g. Jaccard's similarity index) because the result is highly influenced by the difference in the species richness of these segments. Another method is needed if the objective is to determine the similarity of the segments 
on the base of natural conditions. One possibility is to use the indicator values of the individual species. That is why we used Ellenberg's indicator values (Ellenberg et al. 1992) to describe the characteristics of the landscape. Different forms of this system are widely used. Up to end of 2010, the database ISI Web of Knowledge (www isiwebofknowledge.com) recorded at least 393 papers on bioindication using indicator values and the first paper was published in 1982 (Degorski 1982).

The aim of this paper is:

- to analyze the landscape in a small area near Lánov based on the floristic structure of the vegetation cover in the biotopes present in the different segments of that landscape;

- to present an analysis of the flora based on Ellenberg's indicator values, which is rarely done compared to evaluation using phytosociological relevés.

This reveals that the current landscape and its vegetation cover is a result of the interaction of natural conditions, current management and other usage.

\section{Material and methods}

\section{Location and characteristics of the area of interest}

The area of 106.4 ha monitored is situated in the protected zone of the Krkonoše National Park about $4 \mathrm{~km}$ east of Vrchlabí (Fig. 1). It is located in the foothills of the Giant Mountains at the border between Horní Lánov and

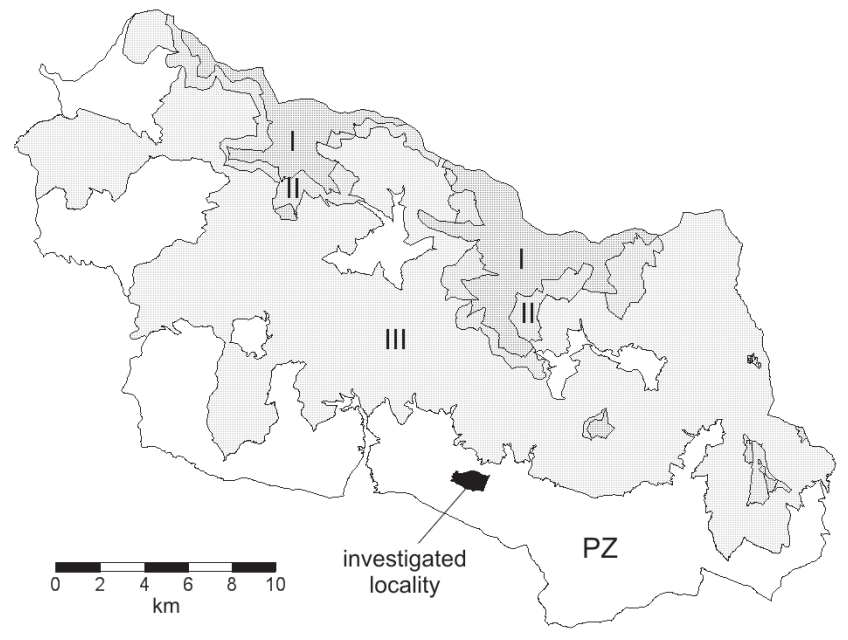

Fig. 1 Location of the area investigated in the protected zone (PZ) of the Krkonoše National Park. Positions of Ist to IIIrd zones of nature protection in the National Park are indicated.

Prostřední Lánov. The northwest boundary is marked by the Pekelský stream and the eastern boudary is the border between Prostřední Lánov and Čistá. The boundary in the south is the road from Horní Lánov through Bíner to Černý Důl (Fig. 2). The altitude varies between 499 and $657 \mathrm{~m}$ a.s.l.

The area analyzed is located near the southern part of the Krkonošský region (code 1.68), where in terms of biogeography it gradually becomes the Podkrkonošský region, 1.37) (Culek et al. 1996). This area belongs to Meso-

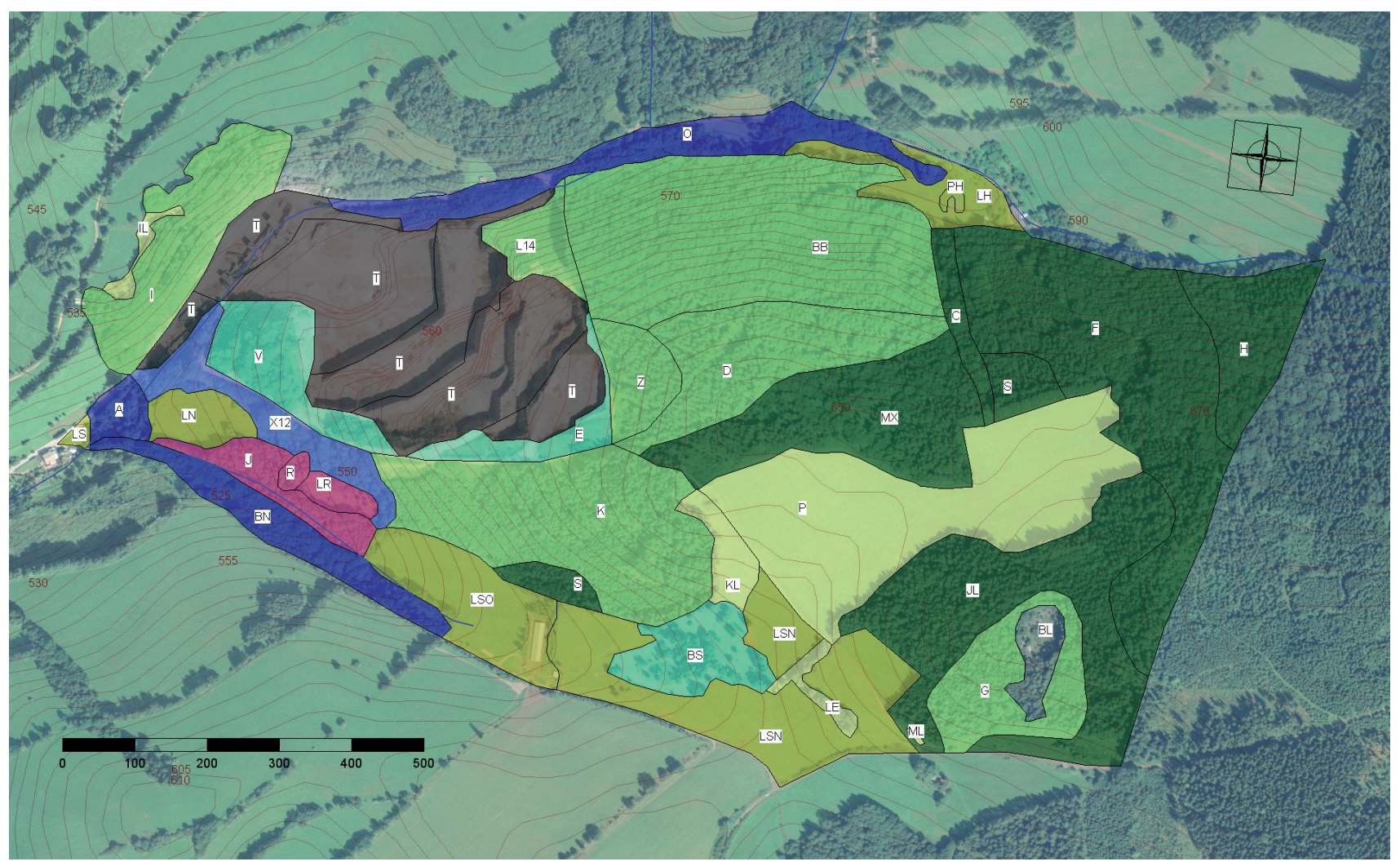

Fig. 2 The study area with the different landscape segments (see Fig. 3 for the colour legend for the classification groups). Ortophoto 2001 is superimposed on the map. The distance between altitudinal contour lines is $5 \mathrm{~m}$. 
phyticum, subdistrict 56c (Trutnovské Podkrkonoší; Skalický 1988).

Long slopes, especially those with a northeastern exposure are typical of this area. Palaeozoic and Proterozoic granular limestone and dolomites cover about $2 / 3$ of the area. The southern third of the area is formed by chlorit-sericitic phylits of the same period with a green slate insert in the centre. Especially at the margins there are Pleistocene deluvial and deluviofluvial sediments, near the stream deluvial sediments of a fluvial plain (Holocene). In the west of the area monitored there are sporadic aleuropelites (sandstones) of the upper Paleozoicum.

Soil in the area is predominately of the Kambizem modal, Glej modal in alluvium and Pseudoglej histic type in the area of Bíner, and Kambizem gleyic and dystric in the surrounding areas, and Fluvizem modal occurs in the north-eastern part of the area (terminology follows Kozák et al. 2010).

The area lies on the border between the mild warm zone MT4 and cool zone $\mathrm{CH} 7$ according to the updated Quitt's classification (Tolasz 2007).

The area monitored is drained by the Pekelský creek, which flows through the quarry (with two big tributaries on the left side). There is a large area with springs covered by species-rich fen vegetation close to Bíner (segment BS). In terms of the landscape characteristics of altitude, climate and vegetation cover / land-use, the area is transitional between an agricultural and forest landscape (Matěj$\mathrm{ka} 2010$ ). According to the data in the land register (data 2003), the KES index (Löw and Míchal 2003, pp. 241-245) varies between 1.46 for the area around Horní Lánov and 0.45 for that around Prostřední Lánov. Values of 0.4-0.8 correspond to an intensively cultivated landscape with a significant level of (agro) industrial elements and values of 0.9-2.9 indicate a common cultural landscape.

In terms of forest typology (Viewegh et al. 2003) the area is located on the border of the 4th and 5th forest alti- tudinal zones. Edaphic series W (limestone) and S (nutrient-medium) predominate here, with the damp areas along the streams categorized as L (alluvial soils on floodplains), $\mathrm{U}$ ('unstable' soils in ravines and gulleys) or $\mathrm{V}$ (moist to wet) (based on the maps of the Institute for Forest Management (ÚHÚL), Brandýs nad Labem, at 2007; see www.uhul.cz).

Potential vegetation in this area is the association Dentario enneaphylli-Fagetum (Neuhäuslová et al. 1998). The geobotanical reconstruction map indicates that most of the area should be covered by forests of sub-alliance Eu-Fagenion and of alliance Alnion incanae on alluvium.

Vegetation cover is influenced by the long-term effect of human activities. Forest-free areas were created accidentally by human intervention. In the past, large areas were deforested and converted to agricultural land (pastures, meadows and fields). The basic negative effect on the area resulted from the quarrying of limestone, eutrophization and ruderalization (especially near the roads, buildings, car parks, stock pile of quarried limestone), planting of evergreen woody species (especially Picea abies) that do not normally grow in this area.

\section{Field survey}

Based on detailed floristic surveys the area was divided into 36 segments (Fig. 2, Table 1) each of which includes a characteristic but relatively homogenous complex of environmental factors and vegetation cover. In the BL segment, three parts were analyzed separately because they have significantly different vegetation structures. Lists of species were compiled for each segment separately based on the results of many surveys. From 2002 to 2004, a detailed evaluation of the vegetation was carried out using the methods of mapping biotopes in NATURA 2000 (Chytrý et al. 2001) and the results of 92 phytosociological relevés typical of this valuable association (Málková 2005). The species inventory of the area was carried out from 2005 to 2010.

Table 1 Basic features of the landscape segments.

Classification - classification group according to Fig. 2. L (light conditions), T (temperature), W (water availability), A (soil acidity), N (nitrogen activity) - indices calculated based on the species counts in the Ellenberg's ecoindication classes (\%). PCA1 and PCA2 - the PCA ordination score calculated based on the share of species in the ecoindication classes. Cover type: forest - forest prevails in part of the area; dry - partially to fully open woody stand on mesophilous to dry soils; wet - partially to fully open woody stand or forest-free biotopes on moist to wet soils.

\begin{tabular}{|c|c|c|c|c|c|c|c|c|c|c|c|c|}
\hline Segment & $\begin{array}{l}\text { Area } \\
\text { (ha) }\end{array}$ & $\begin{array}{c}\text { Number } \\
\text { of species }\end{array}$ & Classification & $\begin{array}{c}\mathrm{L} \\
\mathrm{I}_{7-9 \mid 1-3}\end{array}$ & $\begin{array}{c}\mathrm{T} \\
\mathrm{I}_{6-9 \mid 1-4} \\
\end{array}$ & $\begin{array}{c}W \\
I_{8-12 \mid 1-5} \\
\end{array}$ & $\begin{array}{c}A \\
I_{6-9 \mid 1-4} \\
\end{array}$ & $\begin{array}{c}N \\
I_{6-9 \mid 1-4} \\
\end{array}$ & PCA1 & PCA2 & $\begin{array}{c}\text { Cover } \\
\text { type }\end{array}$ & Short description, comments \\
\hline $\mathrm{T}$ & 12.790 & & & & & & & & & & $\begin{array}{l}\text { bare } \\
\text { soils }\end{array}$ & $\begin{array}{l}\text { Operational quarry with buildings, } \\
\text { stone crusher and special-purpose } \\
\text { built communications }\end{array}$ \\
\hline K & 7.062 & 115 & B000 & 28.7 & 12.5 & -71.3 & 19.4 & 5.4 & 3.32 & -2.62 & forest & $\begin{array}{l}\text { Mixed forest (Betula pendula and } \\
\text { Picea abies prevails) with ruderalized } \\
\text { fringe phytocoenosis }\end{array}$ \\
\hline BB & 10.072 & 112 & B000 & 6.5 & 14.5 & -72.3 & 50.7 & 7.3 & 3.96 & -2.60 & forest & $\begin{array}{l}\text { Strongly-sloping herbaceous plant- } \\
\text { rich beech woodland with a large } \\
\text { number of protected and endan- } \\
\text { gered species }\end{array}$ \\
\hline I & 3.653 & 145 & B000 & 18.2 & 19.2 & -69.3 & 61.7 & 0.8 & 1.49 & -2.21 & forest & $\begin{array}{l}\text { Strongly-sloping calcicolous beech } \\
\text { woodland with rocks; large number } \\
\text { of species of conservation-importance }\end{array}$ \\
\hline
\end{tabular}




\begin{tabular}{|c|c|c|c|c|c|c|c|c|c|c|c|c|}
\hline Segment & $\begin{array}{l}\text { Area } \\
\text { (ha) }\end{array}$ & $\begin{array}{l}\text { Number } \\
\text { of species }\end{array}$ & Classification & $\begin{array}{c}L \\
I_{7-9 \mid 1-3}\end{array}$ & $\begin{array}{c}T \\
I_{6-9 \mid 1-4}\end{array}$ & $\begin{array}{c}W \\
I_{8-12 \mid 1-5}\end{array}$ & $\begin{array}{c}A \\
I_{6-9 \mid 1-4}\end{array}$ & $\begin{array}{c}N \\
I_{6-9 \mid 1-4}\end{array}$ & PCA1 & PCA2 & $\begin{array}{l}\text { Cover } \\
\text { type }\end{array}$ & Short description, comments \\
\hline $\mathrm{MX}$ & 5.299 & 80 & B001 & 1.3 & 16.7 & -67.7 & 34.8 & 7.8 & 4.48 & -1.84 & forest & Mixed, degraded, species-rich stand \\
\hline L14 & 1.083 & 123 & B000 & 21.6 & 4.8 & -67.3 & 51.3 & 10.1 & 2.57 & -1.74 & forest & $\begin{array}{l}\text { Clear-cut strongly-sloping herba- } \\
\text { ceous plant rich beech woodland } \\
\text { with dense spontaneous tree regen- } \\
\text { eration; area adjacent to the quarry } \\
\text { was quarried in } 2010\end{array}$ \\
\hline $\mathrm{F}$ & 9.345 & 80 & B001 & -2.6 & 10.3 & -70.8 & 51.0 & 19.7 & 5.66 & -1.31 & forest & $\begin{array}{l}\text { Degraded herbaceous plant rich } \\
\text { beech woodland, partly cut and } \\
\text { dramatically opened to light }\end{array}$ \\
\hline $\mathrm{D}$ & 4.142 & 178 & B000 & 28.1 & 14.4 & -59.9 & 50.0 & 16.4 & 1.63 & -1.03 & forest & $\begin{array}{l}\text { Degraded herbaceous plant rich } \\
\text { beech woodland with a high } \\
\text { representation of Picea abies and } \\
\text { Abies alba }\end{array}$ \\
\hline $\mathrm{H}$ & 2.474 & 69 & B001 & -24.6 & -9.4 & -72.4 & 42.3 & 24.6 & 7.18 & -0.91 & forest & $\begin{array}{l}\text { Herbaceous plant rich beech wood- } \\
\text { land on a slope in which sometimes } \\
\text { a high proportion of Abies alba and } \\
\text { Picea abies sometimes prevails; ele- } \\
\text { ments of scree forest occur on parts of } \\
\text { the steep slopes }\end{array}$ \\
\hline G & 2.607 & 114 & B000 & 25.0 & 9.1 & -60.6 & 56.5 & 18.7 & 1.69 & -0.70 & forest & $\begin{array}{l}\text { Mixed forest stand with a high } \\
\text { proportion of Picea abies adjacent } \\
\text { to the abandoned limestone quarry; } \\
\text { undergrowth is that of a herbaceous } \\
\text { plant-rich beech woodland }\end{array}$ \\
\hline Z & 1.303 & 137 & B000 & 22.9 & 4.3 & -63.8 & 45.1 & 15.5 & 2.13 & -0.59 & forest & $\begin{array}{l}\text { Degraded herbaceous plant rich } \\
\text { beech woodland; high cover of } \\
\text { shrubs; many species of conserva- } \\
\text { tion-importance; area licensed for } \\
\text { quarrying limestone }\end{array}$ \\
\hline $\mathrm{X} 12$ & 1.939 & 59 & B01 & 12.3 & 33.3 & -65.4 & 50.0 & 18.4 & 3.31 & -0.37 & forest & $\begin{array}{l}\text { High dense vegetation with natural } \\
\text { tree regeneration and remnants of } \\
\text { the original beech woodland }\end{array}$ \\
\hline JL & 7.312 & 96 & B001 & 12.0 & 0.0 & -60.8 & 36.5 & 22.1 & 3.41 & 0.06 & forest & $\begin{array}{l}\text { Even-aged spruce stand in the pit of } \\
\text { the abandoned quarry and original } \\
\text { herbaceous plant rich beech wood- } \\
\text { land with degraded undergrowth }\end{array}$ \\
\hline C & 0.742 & 55 & B001 & -7.8 & 11.1 & -63.6 & 41.9 & 34.1 & 6.07 & 0.50 & forest & $\begin{array}{l}\text { Maple stand on an old farm-track; } \\
\text { herbaceous plant layer corresponds } \\
\text { to that of a degraded herbaceous } \\
\text { plant rich beech woodland }\end{array}$ \\
\hline$S$ & 1.262 & 82 & B001 & 10.4 & -5.9 & -56.7 & 43.8 & 29.9 & 4.12 & 0.84 & forest & $\begin{array}{l}\text { Originally wet fir beech woodland, } \\
\text { now spruce monoculture, some- } \\
\text { times with elements of the original } \\
\text { vegetation in the undergrowth }\end{array}$ \\
\hline $\mathrm{BN}$ & 2.053 & 109 & B1 & 7.8 & 1.6 & -43.2 & 68.6 & 54.7 & 3.43 & 2.50 & forest & $\begin{array}{l}\text { Valley with ash-alder alluvial wood- } \\
\text { land and herbaceous plant rich } \\
\text { beech woodland on adjacent slopes; } \\
\text { botanically valuable area }\end{array}$ \\
\hline BL_D & $(0.7661)$ & 118 & $\mathrm{~A} 1$ & 61.7 & 4.3 & -3.1 & 42.3 & -11.7 & -4.11 & -0.85 & dry & $\begin{array}{l}\text { Abandoned limestone quarry with } \\
\text { species rich vegetation - bottom of } \\
\text { the quarry }\end{array}$ \\
\hline BL_P & & 139 & $\mathrm{~A} 0$ & 53.3 & 23.4 & -63.5 & 46.3 & -10.1 & -2.08 & -4.09 & dry & $\begin{array}{l}\text { Abandoned limestone quarry with } \\
\text { species rich vegetation - plateau }\end{array}$ \\
\hline BL_S & & 80 & A0 & 52.5 & 25.0 & -77.6 & 68.6 & -14.9 & -3.82 & -6.64 & dry & $\begin{array}{l}\text { Abandoned limestone quarry with } \\
\text { species rich vegetation - walls of } \\
\text { the quarry }\end{array}$ \\
\hline BS & 1.883 & 220 & A0 & 57.3 & 11.3 & -21.4 & 51.4 & 0.0 & -2.32 & -0.16 & dry & $\begin{array}{l}\text { Species-rich waterlogged swampy } \\
\text { meadow and deciduous grove; } \\
\text { registered botanical locality }\end{array}$ \\
\hline
\end{tabular}




\begin{tabular}{|c|c|c|c|c|c|c|c|c|c|c|c|c|}
\hline Segment & $\begin{array}{r}\text { Area } \\
\text { (ha) }\end{array}$ & $\begin{array}{l}\text { Number } \\
\text { of species }\end{array}$ & Classification & $\begin{array}{c}\mathrm{L} \\
\mathrm{I}_{7-9 \mid 1-3}\end{array}$ & $\begin{array}{c}T \\
I_{6-9 \mid 1-4} \\
\end{array}$ & $\begin{array}{c}W \\
I_{8-12 \mid 1-5}\end{array}$ & $\begin{array}{c}A \\
I_{6-9 \mid 1-4}\end{array}$ & $\begin{array}{c}N \\
I_{6-9 \mid 1-4}\end{array}$ & PCA1 & PCA2 & $\begin{array}{l}\text { Cover } \\
\text { type }\end{array}$ & Short description, comments \\
\hline $\mathrm{E}$ & 1.062 & 247 & $\mathrm{~A} 0$ & 60.6 & 37.9 & -61.2 & 57.0 & 5.6 & -3.24 & -3.11 & dry & $\begin{array}{l}\text { Xerophilous vegetation in segments } \\
\text { in the operational quarry, access } \\
\text { road; a high share of synanthropic } \\
\text { species }\end{array}$ \\
\hline V & 2.236 & 183 & A0 & 46.4 & 27.6 & -72.1 & 61.7 & 2.0 & -1.20 & -2.80 & dry & $\begin{array}{l}\text { Sparse calcicolous beech woodland } \\
\text { around rocks; a substantial part } \\
\text { quarried in } 2010\end{array}$ \\
\hline IL & 0.255 & 141 & $\mathrm{CO}$ & 66.4 & 30.0 & -69.4 & 55.8 & -15.4 & -4.42 & -4.17 & dry & $\begin{array}{l}\text { Species-rich herbaceous plant edge } \\
\text { and flowery mesophilous to dry } \\
\text { meadow (mown and grazed by } \\
\text { sheep) }\end{array}$ \\
\hline $\mathrm{KL}$ & 0.791 & 88 & $\mathrm{CO}$ & 71.8 & 27.5 & -63.6 & 45.1 & -11.8 & -3.54 & -1.65 & dry & $\begin{array}{l}\text { Mesophilous to xerophilous flowery } \\
\text { meadow on slope with small rocks; } \\
\text { regularly mown }\end{array}$ \\
\hline LE & 0.384 & 113 & $\mathrm{CO}$ & 65.7 & 42.0 & -58.7 & 70.3 & 8.5 & -3.26 & -0.36 & dry & $\begin{array}{l}\text { Mesophilous scrub with a spe- } \\
\text { cies-rich herbaceous plant under- } \\
\text { growth }\end{array}$ \\
\hline $\mathrm{ML}$ & 0.026 & 90 & $\mathrm{CO}$ & 69.8 & 36.6 & -61.1 & 63.0 & 14.9 & -3.74 & -2.04 & dry & $\begin{array}{l}\text { Slightly ruderalized herbaceous } \\
\text { plant edge close to the forest }\end{array}$ \\
\hline$P$ & 8.978 & 113 & $\mathrm{CO}$ & 75.2 & 28.1 & -57.4 & 65.6 & 25.8 & -2.81 & 0.11 & dry & $\begin{array}{l}\text { Species-poor reclaimed meadow, } \\
\text { mown and grazed by cattle; some- } \\
\text { times with remnants of a spring }\end{array}$ \\
\hline LSN & 5.908 & 125 & $\mathrm{C} 1$ & 74.2 & 20.8 & -27.2 & 41.1 & -7.3 & -4.64 & -1.40 & dry & $\begin{array}{l}\text { Reclaimed mesophilous meadow } \\
\text { with several springs; mown and } \\
\text { grazed by cattle }\end{array}$ \\
\hline A & 0.573 & 113 & B1 & 49.0 & 27.8 & -26.9 & 66.7 & 56.5 & -0.67 & 4.38 & wet & $\begin{array}{l}\text { Unmanaged degraded mesophilous } \\
\text { to wet lawn in an old orchard with } \\
\text { ruins, a timber yard and part of the } \\
\text { parking lot (2010) }\end{array}$ \\
\hline 0 & 3.162 & 202 & B1 & 38.3 & 14.0 & -26.1 & 68.0 & 42.9 & 0.11 & 1.88 & wet & $\begin{array}{l}\text { Degraded species-rich alluvial } \\
\text { ash-alder woodland, locally sparse; } \\
\text { high coverage of protected species }\end{array}$ \\
\hline LH & 1.406 & 123 & $\mathrm{C} 1$ & 64.0 & 27.3 & -32.4 & 57.8 & 20.4 & -2.42 & 1.36 & wet & $\begin{array}{l}\text { Mesophilous to waterlogged mead- } \\
\text { ow with small springs, partly mown } \\
\text { and/or grazed by sheep, unman- } \\
\text { aged tall herbaceous plants with } \\
\text { Filipendula ulmaria in parts }\end{array}$ \\
\hline LN & 0.923 & 62 & $\mathrm{C} 1$ & 60.3 & 14.3 & -36.5 & 68.8 & 34.0 & -1.63 & 4.02 & wet & $\begin{array}{l}\text { Previously reclaimed mesophilous } \\
\text { meadow, mown }\end{array}$ \\
\hline LS & 0.118 & 67 & $\mathrm{C} 1$ & 66.1 & 22.7 & -52.5 & 65.8 & 25.0 & -1.77 & 1.77 & wet & $\begin{array}{l}\text { Fairly representative mesophilous } \\
\text { meadow with Arrhenatherum elatius } \\
\text { along the Pekelský creek; mown } \\
\text { several times per year }\end{array}$ \\
\hline LSO & 2.834 & 50 & $\mathrm{C} 1$ & 59.2 & 0.0 & -33.3 & 68.4 & 33.3 & -0.63 & 4.25 & wet & $\begin{array}{l}\text { Reclaimed meadow with elements } \\
\text { of mesophilous Arrhenatherum } \\
\text { elatius meadow and pastures (cattle } \\
\text { grazing; fenced) }\end{array}$ \\
\hline $\mathrm{PH}$ & 0.091 & 99 & $\mathrm{C} 1$ & 64.2 & -13.2 & 7.7 & 33.9 & 4.7 & -3.45 & 2.44 & wet & $\begin{array}{l}\text { Species-rich, slightly ruderalized } \\
\text { spring meadow with many species } \\
\text { of conservation importance; grazed } \\
\text { by sheep }\end{array}$ \\
\hline J & 1.246 & 46 & $D$ & 34.9 & 33.3 & -16.7 & 81.5 & 64.1 & -0.43 & 7.75 & wet & $\begin{array}{l}\text { Hydrophilous young dense maple } \\
\text { stand }\end{array}$ \\
\hline LR & 0.408 & 32 & $\mathrm{D}$ & 48.1 & 23.1 & -32.0 & 58.8 & 37.0 & -1.75 & 4.75 & wet & $\begin{array}{l}\text { Degraded unmanaged mesophilous } \\
\text { to wet meadow }\end{array}$ \\
\hline $\mathrm{R}$ & 0.167 & 47 & $\mathrm{D}$ & 54.3 & 4.0 & 13.6 & 57.7 & 40.5 & -1.96 & 6.73 & wet & $\begin{array}{l}\text { Ruderalized reed bed with tree } \\
\text { regeneration in depressions in the } \\
\text { terrain between maple stand and } \\
\text { unmanaged meadow }\end{array}$ \\
\hline
\end{tabular}




\section{Data processing}

Only floristic data on the presence of species in each segment were processed in this paper. The question of the floristic similarity of the segments should resolve their classification. In this way the variability in the floristic composition of the whole area monitored will be described. Segments were classified on the basis of presence/absence of all the species recorded using the agglomerative hierarchy method of average distance, with the distance (dissimilarity) measured in terms of the complement of Sörensen's index of similarity (1-S) (e.g. McCune and Grace 2002). Sörensen's coefficient was chosen because the similarity of segments does not depend on the species richness as is the case with other measures (e.g. Euclidean distance).

Species were categorized into the following groups: trees, shrubs (woody species with a height of up to $2 \mathrm{~m}$ ), indigenous plants (herbaceous species of plants that are not included in the following category) and synanthropic taxa (i.e. species of herbaceous plants that occur mainly in ruderal and weed communities; this was done in the Giant Mountains and their foothills). The list of those species that are considered to be synanthropic is in the appendix. The last two categories are distinguished relatively subjectively. Nevertheless, this classification was used because the ratio of the number of species in both these categories (later called the synanthropization index) can be easily interpreted. While interpreting the level of synanthropization there is a need to remember that it is only a relative representation of synanthropic species, e.g. the invasion by one species of a species rich segment has a lower effect in increasing this index than that it does on a species poor segment.

The environmental conditions were defined in terms of Ellenberg's indicator values (Ellenberg et al. 1992). Species counts in classes defined in terms of light (L), temperature $(T)$, soil wetness (water availability; W), soil reaction $(\mathrm{A})$ and nitrogen activity $(\mathrm{N})$ were evaluated for each landscape segment. In the literature the factor $\mathrm{N}$ is described in terms of nitrogen availability but the index indicates the speed of the nitrogen cycle rather than the supply of this element in the ecosystem. This is why it is better to talk about "activity", see (Matějka 1993). Other authors describe this factor using a general term "fertility" (e.g. Hill et al. 2000). Indicator values for continentality were not used for two reasons: most species are indifferent to this factor and the use of this index is only useful when comparing widely separated geographical areas.

Species were separated into classes. Each class contains species with an index equal to a certain value. Classes are marked by letters tagging a particular ecological factor and given value. Species in a particular segment that have a particular value for a particular environmental factor are expressed as a relative frequency, e.g. $\mathrm{L}_{1}+\ldots+\mathrm{L}_{9}=1$. Taxa that do not have an indicator value or for which the value is unknown were not included in the analysis. In the literature mean indicator values are usually arithmetic averages weighted by taking into consideration the species' representation (e.g. coverage). This is possible if data consists of phytosociological relevés (Diekmann 1995, Brunet et al. 2000, Hill et al. 2000), but not if it consists of floristic data (or other data of presence/absence). Some authors also challenge the value of a weighted species presence (Kafer and Witte 2004). As an arithmetic average cannot be calculated using ordinal values such as indicator values, simplified indicator values (indices) are proposed. Such indicator values (generally for factor $\mathrm{f}$ ) were calculated from simple relative species frequencies in individual classes $\left(f_{1}\right.$ to $f_{9}$, resp. $f_{1}$ to $f_{12}$ in the case of soil wetness), e.g.

$$
I_{6-9 \mid 1-4}=f_{6}+f_{7}+f_{8}+f_{9}-f_{1}-f_{2}-f_{3}-f_{4} \text {. }
$$

Index $\mathrm{I}_{7-9 \mid 1-3}$ was used analogously, as well as similar indices for water availability.

Data on the relative share of individual classes based on all the Ellenberg's values for all five environmental factors were processed using principal component analysis, PCA. The calculation was based on a correlation matrix of the parameters.

Maps were produced using the programme TopoL $\mathrm{xT}$, version 9.5 (www.topol.cz). Statistical analyses were carried out using Statistica software, version 8 (product of the StatSoft Inc.). The ordination results were plotted using PlotOA software (www.infodatasys.cz/software).

\section{Results and discussion}

\section{Species richness}

In the whole of the area monitored, 517 species of vascular plants were recorded from 2002 to 2010,30 of them were trees, 26 shrubs, 351 indigenous plants and 109 synanthropic taxa. The average synanthropization index was $19.7 \%$. The highest indices were recorded in segments P (44\%), 4 (37\%), O (32\%), LR (30\%), ML and V (both $29 \%$ ), the vegetation in which was substantially affected by different factors. For instance, the re-cultivated pasture (segment $\mathrm{P}$ ) included not only pasture, but also unmanaged ruderal borders and a grassy path. In segment $E$, there is unmanaged vegetation and no management of the access paths in the functional quarry where invasive species occurred. The high percentage of synanthropic species in segment $\mathrm{O}$ is associated with the runoff from the pasture and other sites with buildings and the unmanaged landscape borders of the path (e.g. where the following invasive species occurred: Reynoutria japonica, Solidago canadensis and Impatiens parviflora). In segment LR, the high number of synanthropic species is associated with runoff from the pasture, the sheep-cot and the long time for which it has not been managed.

On the other hand, the lowest synanthropization indices $(<10 \%)$ were recorded in segments with closed for- 
ests $(\mathrm{H}, \mathrm{BB}$ and $\mathrm{F})$, where synanthropic species mostly only grow along the paths that go through these stands.

Segment E with 247 species is the richest in terms of species. In this segment there are lots of microclimatically different locations. Xerophilous vegetation predominates in the operational quarry. Synanthropic species are abundant in the surroundings of the access paths from the outbuildings up to the highest levels in the quarry. In this segment, there is locally a high cover of evergreen trees and small depressions in the terrain where shady and humid places occur. Different elements occur close to one another in neighbouring associations, which means there are even species with different indicator values to the chosen ecological factors (especially wetness and light).

Another species-rich segment is segment BS, where 220 species were recorded. In this segment there are two fenced wet fen meadows divided from each other by a small woodlot with a heterogeneous mixture of trees. Heliophilous and hygrophilous species predominate and coexist there along with shade tolerant and mesophilous species. Some xerophilous species also occur sporadically at the margin of this segment.

The richest species forest segment is $\mathrm{D}$ (178 species). Compared to the other forest segments, there is an increased level of synanthropization (24\%) there. The high number of species is due to the many ruderal species that occur at the borders of the forest and along the paths, as well as the hygrophilous vegetation that occurs in some parts of the segment. Wind damage to the tree stand that occurred in July 2009 has also had a role in determining the species richness there.

The number of species in a given area is not dependent on the size of segment. This may be due to the fact that the segments are relatively heterogeneous in terms of micro-sites, which is largely caused by anthropogeneous influences (e.g. ruderalization in the surroundings of roads and buildings, increased exposure to light in places where trees have been felled or windblown).

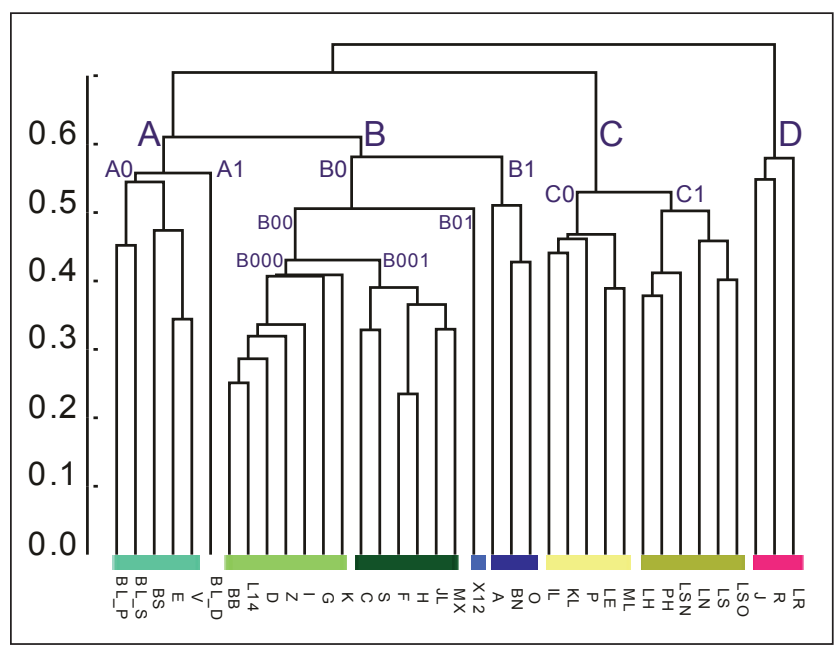

Fig. 3 The average clustering of landscape segments into groups, which was calculated using species presence/absence. Similarities were evaluated using Sörensen's index.

\section{Classification of segments}

The classification of the segments (Fig. 3) based on their structure revealed that there are four basic groups: A-D. When viewed in more detail then other subclasses in terms of their ecology can be identified (Tab. 1). The final map of the different groups of segments includes elements of landscape cover, but it is not a vegetation map or a biotope map as defined by the system NATURA 2000 (Härtel et al. 2009).

\section{Bioindication}

We assessed 5.4\% of all the species recorded as indifferent to light intensity or this indicator value was not set for them. Most of the species (32.7\%) are relatively light-demanding with an index of 7. Forest-free area covers less than $40 \%$ of the area monitored and these places are richer in species than forest stands. Species with a range of different indicator values for this factor occurred there. Indices $\mathrm{I}_{7-9 \mid 1-3}$ and $\mathrm{I}_{6-9 \mid 1-4}$ have similar predictive capabilities (based on correlation coefficient comparison between these indices and indicator values using the arithmetic average; Tab. 2).

Of all the species, $38.1 \%$ have wide ecological amplitudes in terms of temperature or this indicator value was not set for them. Most of the species recorded have indicator values of either $5(25.0 \%)$ or $6(26.7 \%)$. Nearly all the species had indices of 3-8 for this environmental factor. The index $\mathrm{I}_{6-9 \mid 1-4}$ (Tab. 2) appears to be the most suitable for evaluating the temperature conditions.

Of all the species, $13.5 \%$ were evaluated as indifferent to the availability of water or did not have indicator values set for this ecological factor. Most of the species present had an indicator value for this factor of 5 (28.0\% of all species). Species with the values $2-11$ were also recorded there. These results indicate that very different locations can occur there near water (segments $\mathrm{O}, \mathrm{PH}$ ) or very dry places (E). Of the three indices used the index $\mathrm{I}_{8-12 \mid 1-5}$ (Tab. 2) seems to be the optimal one.

Of all the species, $32.5 \%$ were indifferent to soil reaction or the indicator value for this factor for them is not set. Most of the species had an indicator value of 7 (23.4\% of all species) for this factor. Species with indicator values for a wide range of values of $\mathrm{pH}$ were present. The index

Table 2 Correlation coefficients ( $r$ ) between bioindication indices and eco-indices calculated as arithmetic means; based on the presence/ absence of species in landscape segments selected.

\begin{tabular}{lll}
\hline Environmental parameter & $\mathrm{I}_{7-9 \mid 1-3}$ & $\mathrm{I}_{6-9 \mid 1-4}$ \\
\hline light conditions $(\mathrm{L})$ & 0.996 & 0.993 \\
temperature $(\mathrm{T})$ & 0.667 & 0.991 \\
soil acidity $(\mathrm{A})$ & 0.938 & 0.948 \\
nitrogen activity (N) & 0.986 & 0.990 \\
\hline
\end{tabular}

\begin{tabular}{llll}
\hline Environmental parameter & $\mathrm{I}_{9-12 \mid 1-4}$ & $\mathrm{I}_{8-12 \mid 1-5}$ & $\mathrm{I}_{7-12 \mid 1-6}$ \\
\hline water availability $(\mathrm{W})$ & 0.885 & 0.969 & 0.943 \\
\hline
\end{tabular}


$I_{6-9 \mid 1-4}$ (Tab. 2) seems to be slightly more suitable for evaluation of soil acidity.

Of all the species, $14.7 \%$ had wide ecological tolerance of nitrogen activity or the indicator value for this factor for them was not set. Species with a wide range of indicator values for this environmental factor occurred with similar incidences (the incidences of species with values of 2-7 were $10-14 \%)$. Both count indices $\mathrm{I}_{7-9 \mid 1-3}$ and $\mathrm{I}_{6-9 \mid 1-4}$ have a similar predictive capability (Tab. 2).

Ellenberg's indicator system has been used to study landscape structure, for example, Okland et al. (2006) studied the agricultural landscape in Norway based on $1 \mathrm{~km}^{2}$ segments. A second example is a study on the effects of landscape on the species composition of the herbaceous plant etage in indigenous forests in Great Britain (Petit et al. 2004).

\section{Ordination using the indicator values of the species}

Based on the ordination analysis of the relative numbers of species in the particular indicator classes of Ellenberg et al. (1992), there are clearly three basic lines (directions in the ordination space) (Fig. 4). The first line is characterized by $\mathrm{L}_{1}-\mathrm{L}_{5}$ classes (shade-tolerant species, mostly forest species), $\mathrm{W}_{5}$ (species with a medium requirement for water) and $\mathrm{A}_{2}$ (species of acid soil). The second line connects species of wet localities $\left(\mathrm{W}_{6}, \mathrm{~W}_{7}\right)$ and those occurring in localities with a higher nitrogen activity $\left(\mathrm{N}_{7}, \mathrm{~N}_{8}\right)$, whose occurrence is related to a higher ordination score along the second axis. The third line is characterized by species with indicator values $\mathrm{W}_{3}, \mathrm{~W}_{4}$ (species of slightly drier localities), $\mathrm{N}_{1}, \mathrm{~N}_{2}$ and $\mathrm{N}_{3}$ (low nitrogen activity) and $\mathrm{A}_{9}$ (species growing on basic soil). Simultaneously, this line is more or less closed to the occurrence of species growing in full-sun $\left(\mathrm{L}_{8}\right)$.

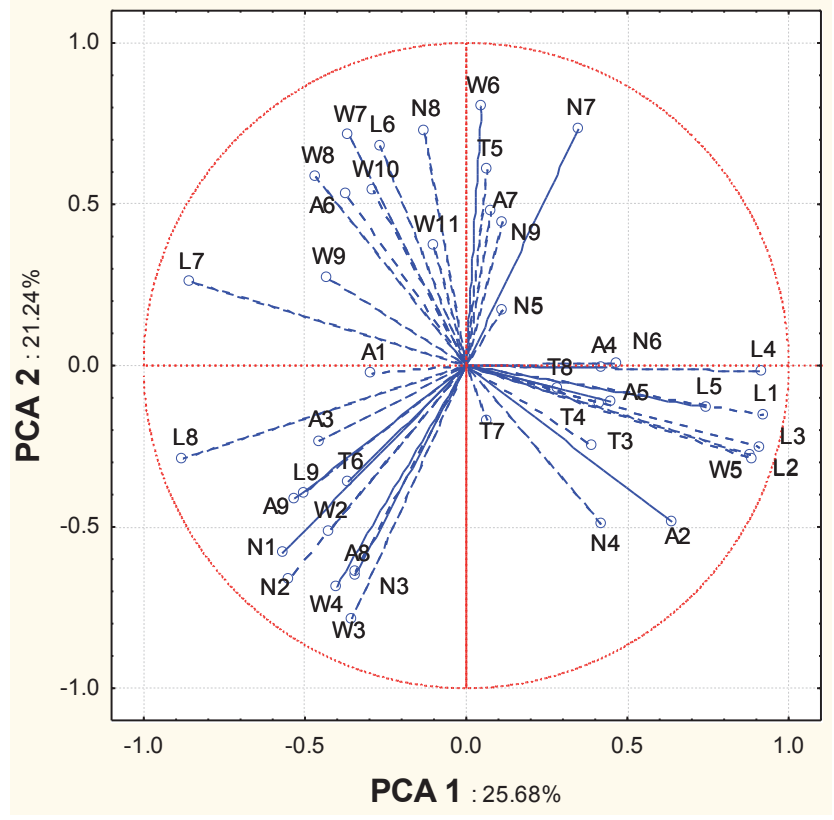

Fig. 4 Space with the first two principal component (PCA) axes localized in terms of the variable - relative share of species of single indicator class according to Ellenberg et al. (1992).
Location of landscape segments within ordination space (Fig. 5) was used to classify the segments into different groups. The typical forest segments occurred mostly on mesophilous sites (located in right hand sector of the ordination space) and the segments with fens on wet, water-logged soils (located in the upper left hand sector) can have a more or less open evergreen tree layer. The third group includes segments on dry soils with xerothermic elements (lower left third of ordination space). Based on the location of a landscape segment in a particular sector of ordination space it was categorized as either "forest", "wet" or "dry" (Table 1). This classification can in some cases appear to be wrong because of the presence of a species belonging to particular ecological class in a segment that does not include the biotope or micro-site of this species can result in the segment being assigned to the wrong group. In this context, the assignment of segment BS to the "dry" group, although biotopes of fen meadows occur there, is such a case. Nonetheless, there are a lot of microsites with dry soils there where Carlina acaulis, Clinopodium vulgare, Euphorbia cyparissias, Galium verum or Securigera varia can be found. The great diversity of microsites in this segment accounts for its high species richness.

In the ordination graph (Fig. 5) those groups of segments that were classified on the basis of the occurrence of particular species, are marked. Most clusters occur only

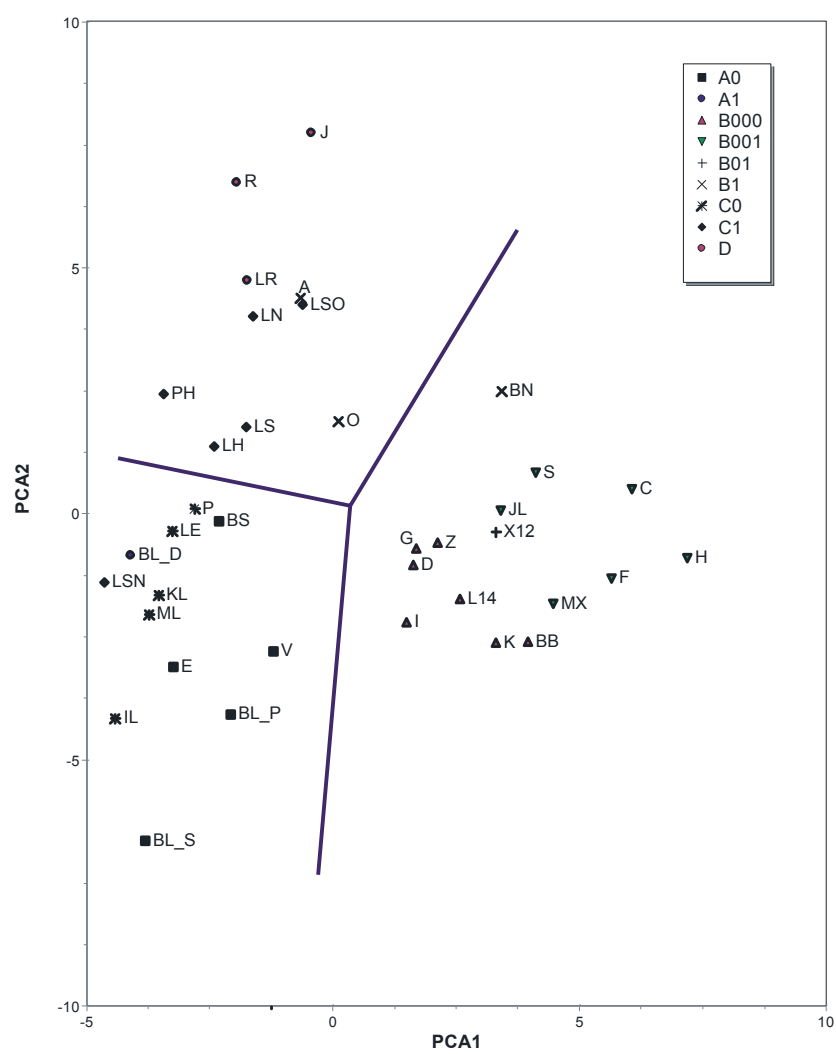

Fig. 5 The position of the segments of landscape in the ordination space of the first two PCA axes calculated on the basis of their relative share of species of single indicator class according to Ellenberg et al. (1992). The segments are classified based on the occurrences of all species (Fig. 2). 
in one of three different groups of segments. In the "dry" group there are the classes A0 (5 landscape segments), A1 (1) and C0 (5), in the "forest" group classes B000 (7), B001 (6) and B01 (1) and in the "wet" group uniquely class D (3 segments) and two other classes represented by one segment in the "dry" group (class C) and one in the "forest" group (class B1), which is probably a result of the heterogeneity of particular segments and variability in the vegetation units within individual segments.

Segments categorized in the "forest", "dry" and "wet" groups differ in species richness. The richest segments are on dry soils and the poorest on waterlogged soils.

The level of synanthropization (Fig. 6) and the score along the first indicator axis are significantly correlated $(r=-0.513 ; p<0.05)$, which is because the most synanthropized sites are open and free of forest. The highest synanthropization index was recorded in segment $\mathrm{P}$ where a mown reclaimed meadow (used as cattle pasture) is the predominant biotope. Other segments with a high synanthropization index are in the operational quarry and this is connected with limestone excavation (transport, material manipulation). The second ordination axis correlates with species richness in terms of the total number of species $(r=-0.510)$, number of species of trees $(r=-0.401)$ and shrubs $(r=-0.410)$. The highest correlation was with the number of "natural plants" $(r=-0.534)$. The segments on dry sites are much richer in species than those on waterlogged soil. This is not the case when there is an increase in variability of (micro)sites within a segment as is the case in segment BS.

\section{Summary}

Detailed surveys carried out from 2002 to 2010 revealed that there are 517 vascular species of plants in the wider surroundings of the lime quarries near Horni Lánov, which consists of an area of 106 ha composed of 36 segments of landscape.

The results of the analyses indicate that the species composition of the vegetation cover in the wider area is mostly influenced by two factors, which are evident from the ordination analysis. The first is the way each segment of landscape is used, which is related to the openness of the tree layer or more precisely the occurrence of non-forest sites in the segment. The second is soil wetness.

Nevertheless, the presence of limestone is an important factor for the plant species composition in the whole region. The different bedrock in the southern part of the area monitored seems to be less important, though it does affect the species composition of the segments in this area and their classification (Figs 2 and 3). This can be given by the fact that only phyllites are found in the area and the soils on the phyllites are apparently influenced by the material transfer from the highly located habitats on calcite bedrock.

The variation in the segments, each of which is described by the list of vascular species of plants recorded there can be evaluated using hierarchical agglomerative classification. On this basis, it is possible to draw a map of the different types of vegetation-cover (example in Fig. 2). Ordination analysis based on the relative representation of species (relative species counts) in particular indicator classes according to Elleberg can bring other information about the im-

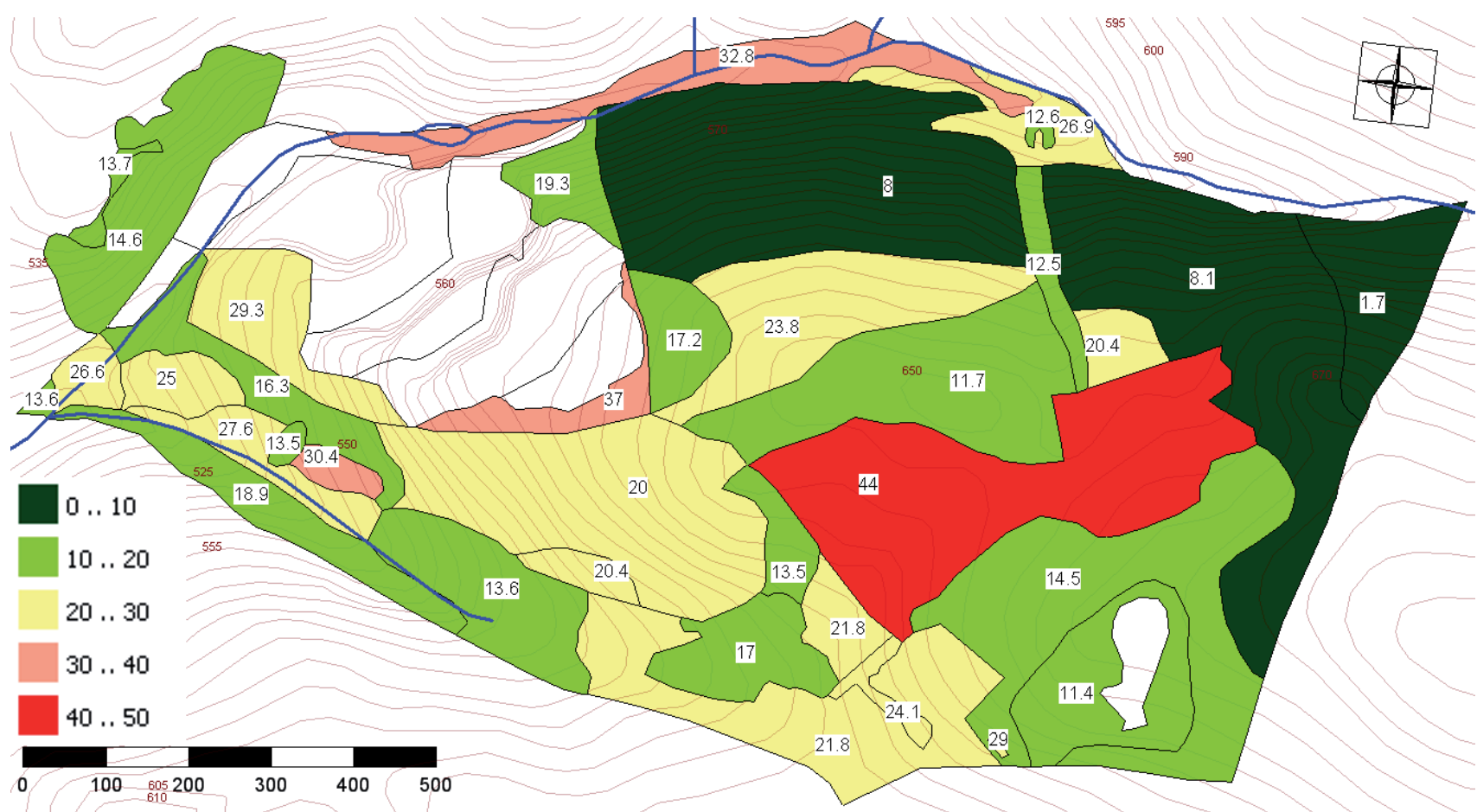

Fig. 6 The landscape segments in the study area classified in terms of their synanthropic index (\%). 
portance of environmental factors in the differentiation of vegetative cover in differently evaluated segments without considering the species richness of those segments.

\section{Acknowledgements}

The detailed study of the flora and vegetation in 20022004 was supported by Krkonošská vápenka Kunčice, Inc. by request of the Administration of the National Park. Floristic surveys in 2005-2010 were supported by specific research projects (No. 2101, 2103, and 2109) funded by the University of Hradec Králové. The analysis of landscape and vegetation was done as part of project 2B06012 of the National research programme II - Biodiversity Management in Krkonoše and Šumava (abbreviation BiodivKrŠu; www.infodatasys.cz/biodivkrsu/projekt.htm), which was funded by the Ministry of education.

\section{REFERENCES}

Brunet J, von Oheimb G, Diekmann M (2000) Factors influencing vegetation gradients across ancient-recent woodland borderlines in southern Sweden. J Veg Sci 11: 515-524.

Culek M (ed.) (1996) Biogeografické členění České republiky. [Biogeographical division of the Czech Republic] Enigma, Praha. In Czech.

Degorski ML (1982) Usefulness of Ellenberg bioindicators in characterizing plant communities and forest habitats on the basis of data from the Range Grabowy in Kampinos Forest. Ekol PolPol J Ecol 0: 453-477.

Diekmann M (1995) Use and improvement of Ellenbergs indicator values in deciduous forests of the boreo-nemoral zone in Sweden. Ecography 18: 178-189.

Ellenberg H, Weber HE, Düll R, Wirth V, Werner W, Paulissen D (1992) Zeigerwerte von Pflanzen in Mitteleuropa. Scripta Geobotanica, Vol. 18. Verlag Erich Goltze KG, Göttingen.

Faltysová H, Mackovčin P, Sedláček M (eds) (2002) Královéhradecko. In: Mackovčin P, Sedláček M (eds) Chráněná území ČR [Protected areas in the Czech Republic], svazek V. AOPK ČR a EkoCentrum Brno, Praha. In Czech.

Farina A (2006) Principles and methods in landscape ecology. Toward a science of landscape. Landscape Series, Vol. 3. Springer, Dordrecht.

Härtel H, Lončáková J, Hošek M (eds) (2009) Mapování biotopů v České republice. Východiska, výsledky, perspektivy. [Habitat mapping in the Czech Republic] AOPK ČR, Praha. In Czech.

Hill MO, Roy DB, Mountford JO, Bunce RGH (2000) Extending Ellenberg's indicator values to a new area: an algorithmic approach. J Appl Ecol 37: 3-15.

Chytrý M, Kučera T, Kočí M (eds) (2001) Katalog biotopů České republiky. [Habitat catalogue of the Czech Republic] AOPK ČR, Praha. In Czech.
Kafer J, Witte JPM (2004) Cover-weighted averaging of indicator values in vegetation analyses. J Veg Sci 15: 647-652.

Kozák J et al. (2010) Soil atlas of the Czech Republic. Czech University of Life Sciences, Prague.

Křenová Z, Hruška J (2012) Proper zonation - an essential tool for the future conservation of the Sumava National Park. Eur J Environ Sci 2: 62-72.

Löw J, Míchal I (2003) Krajinný ráz. [The landscape impression] Lesnická práce, Kostelec nad Černými lesy. In Czech.

Málková J (2007) Geobotanický výzkum a monitoring v širším okolí lomu v Horním Lánově (ochranné pásmo Krkonošského národního parku). [Geobotanical research and monitoring in a wider area near lime quarry in Horní Lánov (buffer zone of the Krkonoše National Park)] Opera Corcontica 44: 353-361. In Czech.

Málková J, Horáková P, Sychrová L (2004) Porovnání floristického složení rostlinných společenstev dvou bučin nad Pekelským potokem v Podkrkonoší. [Floristic comparison of the plant communities in two beech forests above Pekelský Stream in the Krkonoše Piedmont] Práce a studie, Vč. Sb. Př́r. 12: 71-108. In Czech.

Málková J, Horáková P, Sychrová L (2006) Nové a ověřené lokality druhů Monotropa hypophegea Wallr. a Orchis ustulata L. [New and verified localities of Monotropa hypophegea Wallr. and Orchis ustulata L.] Acta Muzei Reginae Hradecensis S.A. 31: 63-66. In Czech.

Matějka K (1993) Diversity of ecological groups of species in cultural forests of South Bohemia. Ekológia 12: 299-316.

Matějka K (2010) Landscape structure/development and vegetation in the example of the transect Vrchlabí - Bílé Labe springs. Opera Corcontica 47 (Suppl. 1): 107-122.

McCune B, Grace JB (2002) Analysis of ecological communities. MjM Software Design, Gleneden Beach, Oregon.

Mikyška R, Deyl M, Holub J, Husová M, Moravec J, Neuhäusl R, Neuhäuslová Z (1969) Geobotanická mapa ČSSR 1. České země. [Geobotanical map of Czechoslovakia. 1. The Czech Lands] Academia, Praha. In Czech.

Neuhäuslová Z, Blažková D, Grulich V, Husová M, Chytrý M, Jeník J, Jirásek J, Kolbek J, Kropáč Z, Ložek V, Moravec J, Prach K, Rybníček K, Rybníčková E, Sádlo J (1998) Mapa potenciální přirozené vegetace České republiky 1 : 500 000. [Map of potential natural vegetation of the Czech Republic] Academia, Praha. In Czech.

Okland RH, Bratli H, Dramstad WE, Edvardsen A, Engan G, Fjellstad W, Heegaard E, Pedersen O, Solstad H (2006) Scale-dependent importance of environment, land use and landscape structure for species richness and composition of SE Norwegian modern agricultural landscapes. Landscape Ecol 21: 969-987.

Petit S, Griffiths L, Smart S S, Smith GM, Stuart RC, Wright SM (2004) Effects of area and isolation of woodland patches on herbaceous plant species richness across Great Britain. Landscape Ecol 19: 463-471.

Tásler R (1990) Geologická mapa ČR. Trutnovsko, 1 : 50 000, list 03-42. Ústřední ústav geologický, Praha.

Tolasz R (ed.) (2007) Atlas podnebí Česka. [Climate atlas of Czechia] ČHÚ, Praha, Olomouc. In Czech.

Viewegh J, Kusbach A, Mikeska M (2003) Czech forest ecosystem classification. J For Sci 49: 85-93. 


\section{Appendix}

\section{List of the synanthropic species recorded in the area studied}

Aegopodium podagraria; Aethusa cynapium; Agrostis gigantea; Alliaria petiolata; Anagallis arvensis; Anthriscus sylvestris; Arabidopsis thaliana; Arctium lappa; Arctium tomentosum; Artemisia vulgaris; Barbarea vulgaris; $\mathrm{Ca}$ lamagrostis epigejos; Campanula ranunculoides; Cannabis sativa; Capsella bursa-pastoris; Carduus acanthoides; Carex hirta; C. muricata; Cirsium arvense; C. vulgare; Convolvulus arvensis; Conyza canadensis; Cuscuta epithymum; C. europaea; Echium vulgare; Elytrigia repens; Epilobium ciliatum; Equisetum arvense; Erigeron acris; E. annuus; Erodium cicutarium; Erophila verna; Erysimum cheiranthoides; Fallopia convolvulus; Galeopsis pubescens; G. tetrahit; Galinsoga parviflora; G. quadriradiata; Galium aparine; Geranium columbinum; G. dissectum; G. pusillum; G. pyrenaicum; G. robertianum; Geum urbanum; Glechoma hederacea; Hypericum humifusum; Chaerophyllum aromaticum; Chelidonium majus; Chenopodium album; C. bonus-henricus; C. polyspermum; Impatiens parviflora; Juncus tenuis; Lactuca serriola; Lamium album; L. purpureum; Lapsana communis; Lolium multiflorum; Malva neglecta; Matricaria discoidea; Medicago falcata; $M$. sativa; Melilotus albus; M. officinalis; Mentha $\times$ verticillata; $M$. arvensis; M. longifolia; Microrrhinum minus; Myosotis arvensis; Myosoton aquaticum; Persicaria lapathifolia; P. maculosa; Pinus mugo; Plantago major; Poa annua; Polygonum aviculare; Potentilla anserina; P. reptans; Reynoutria japonica; Rumex crispus; R. obtusifolius; R. thyrsiflorus; Sedum spurium; Senecio jacobaea; Sherardia arvensis; Silene latifolia subsp. alba; Sinapis arvensis; Sisymbrium officinale; S. strictissimum; Solidago canadensis; Sonchus arvensis; S. asper; S. oleraceus; Spergularia rubra; Stellaria media; Tanacetum vulgare; Taraxacum sect. Ruderalia; Tripleurospermum inodorum; Tussilago farfara; Urtica dioica; Verbascum thapsus; Veronica arvensis; V. hederifolia; Vicia sepium; Vicia tetrasperma; Vicia villosa subsp. villosa; Viola arvensis; $V$. tricolor subsp. tricolor. 